\title{
ISLAM RADIKAL VS ISLAM RAHMAH KASUS INDONESIA
}

\author{
H. Suparman Syukur \\ IAIN Walisongo Semarang \\ Suparman_syukur@yahoo.com
}

\begin{abstract}
Momentum kebebasan demokrasi memberi angin segar bagi kelompok fundamentalis-radikal merangsek ke tengah publik untuk menyuarakan aspirasi politis-ideologisnya. Sialnya, cara, gaya, karakter atau pendekatan yang digunakan kerap berseberangan dengan identitas dan bangunan budaya bangsa ini. Kekerasan kerap menjadi menu tidak asing lagi yang melekat dalam tubuh kelompok fundamentalis-radikal. Dengan berjubahkan agama dan atas nama agama, Islam sebagai agama rahmah dan toleran menjadi kabur dibumi Indonesia ini, tertutupi oleh merebaknya fenomena radikalitas dan ekstrimitas kelompok-kelompok fundamentalis-radikal. Bukan hanya itu, logika radikalitas kelompok fundamentalis-radikal pun berjalan diatas logika demokrasi dan kebebasan menyuarakan pendapat, walau harus mengorbankan keadaban dan keluhuran agama dan bangsa ini.
\end{abstract}

Kata Kunci: islam radikal, islam rahmah, fudamentalsime, islam moderat, NU, dan Muhammadiyah.

\section{PENDAHULUAN}

Salah satu buah dari babak baru Indonesia pasca jebolnya dindingdinding otoritarianisme oleh rezim orde baru adalah tampilnya gaya Islam fundamentalis-radikal di pentas publik. Kelompok fundamentalis-radikal unjuk gigi ke panggung publik sembari menabuh genderang Islamisasi dalam berbagai lini, sektor dan bidang. Kelompok-kelompok Islam fundamental-radikal bersuara lantang yang sarat dengan obsesi politisideologis, salah satunya adalah menjungkirbalikkan logika berbangsa dan bernegara yang selama ini telah mapan dan ajeg. Yakni, mengganti dasar atau ideologi negara dengan konsepsi-konsepsi yang berbau Islam formal. 
Negara Islam dan syariat Islam, misalnya, getol disuarakan oleh kalangan fundamentalis-radikal. Yang sudah terlihat jelas didepan mata kepala bangsa ini adalah syariatisasi peraturan-peraturan daerah (baca: Perda Syariat) di beberapa daerah di Tanah Air. Selain itu, gejala lain sebagai tanda-tanda berseminya kelompok-kelompok fundamentalis-radikal adalah intensitas kekerasan yang acap terjadi atas nama agama, jihad, perjuangan dijalan Allah, amar makruf nahi mungkar, dan semisalnya.

Dalam kaitannya dengan transisi demokratisasi, bila boleh disebut, selain demokrasi dibajak oleh kelompok-kelompok politisi berbendera kepentingan elit dan golongan tertentu, demokrasi di Indonesia juga dibajak oleh kelompok-kelompok fundamentalis-radikal. Momentum kebebasan memberi angin segar bagi kelompok fundamentalis-radikal merangsek ke tengah publik untuk menyuarakan aspirasi politis-ideologisnya. Sialnya, cara, gaya, karakter atau pendekatan yang digunakan kerap berseberangan dengan identitas dan bangunan budaya bangsa ini. Kekerasan kerap menjadi menu tidak asing lagi yang melekat dalam tubuh kelompok fundamentalisradikal. Dengan berjubahkan agama dan atas nama agama, Islam sebagai agama rahmah dan toleran menjadi kabur dibumi Indonesia ini, tertutupi oleh merebaknya fenomena radikalitas dan ekstrimitas kelompok-kelompok fundamentalis-radikal. Bukan hanya itu, logika radikalitas kelompok fundamentalis-radikal pun berjalan diatas logika demokrasi dan kebebasan menyuarakan pendapat, walau harus mengorbankan keadaban dan keluhuran agama dan bangsa ini.

Sebangun dengan tesis-tesis di atas, dalam membaca fenomena kelompok fundamentalis-radikal, menurut tilikan Imdadun Rahmat, ada prakondisi yang menjadi latar belakang kemunculan gerakan fundamentalisradikal. Pra-kondisi itu adalah menganganya kran demokratisasi. Kejatuhan rezim orde baru menjadi momentum tampilnya kelompok Islam fundamentalis-radikal. Kelompok-kelompok ini lahir ditengah atmosfir kebebasan. Gaya gerakan Islam ini berbeda dengan gerakan Islam yang lama seperti NU maupun Muhammadiyah, misalnya. Gerakan Islam fundamentalis-radikal berada diluar kerangka maenstrem proses politik maupun wacana dalam gerakan Islam dominan. ${ }^{1}$

\section{MODEL-MODEL}

Menyeruaknya model Islam fundamentalis-radikal ke tengah panggung dinamika kehidupan berbangsa dan bernegara tak luput mengikutkan isu-isu politis-ideologis. Sebagai misal, isu paling sensitif yang dilekatkan 
pada gerakan fundamentalis-radikal adalah formalisasi Islam dalam bingkai negara yang salah satu manifestasinya adalah penegakan syariat Islam dalam segala aspek, lini dan dimensi. ${ }^{2}$

Istilah lain yang juga kerap digunakan untuk dilabelkan pada kelompok-kelompok fundamentalis-radikal seperti Islam radikal, Islam fundamentalis, Islam militan, Islam garis keras, Islam ekstrim, dan lain-lain. Untuik kepentingan kajian ini, penulis tampaknya untuk sementara lebih cenderung menggunakan istilah fundamentalis-radikal. Selain gerakannya berorietasi pada formalisasi Islam, fundamentalis-radikal kerap mengedepankan cara-cara kekerasan dalam bertindak dan berjuang.

Sedikit menilik akar historisnya banyak pengamat menyebutkan, kemunculan fundamentalis-radikal tidak bisa dilepaskan dari pengaruh keagamaan dan politik Timur Tengah ke Indonesia. Semenjak Islam masuk ke nusantara, hubungan masyarakat Indonesia dengan Timur Tengah sangat kental. Dalam konteks keagamaan, pengetahuan dan politik, transmisi ini dimungkinkan karena posisi Timur Tengah sebagai sentrum yang selalu menjadi rujukan umat Islam. Negara-negara yang memiliki kota-kota suci dan pusat ilmu pengetahuan selalu dikunjungi orang Indonesia, baik yang berhaji, ziarah, maupun belajar. Dari aktivitas ini kemudian muncul berbagai jaringan, baik keulamaan, gerakan dakwah, maupun jaringan gerakan politik. ${ }^{3}$

Fundamentalis-radikal di Indonesia dalam sejarahnya dimulai dari munculnya gerakan DI/TII (Darul Islam/Tentara Islam Indonesia). Gerakan ini memiliki basis di 3 (tiga) wilayah; Jawa Barat, Aceh dan Makassar. Pada awalnya, DI/TII hanya ada di Jawa Barat, dan baru kemudian gerilyawan Aceh dan Makassar ikut bergabung walaupun dengan alasan yang berbedabeda. Gerakan mereka disatukan oleh keinginan untuk menjadikan syariat Islam sebagai dasar negara. ${ }^{4}$ Salah satu pucuk pimpinannya adalah Kartosuwiryo. Ia mencita-citakan negara Islam, dan menjadikan syariat Islam sebagai dasar hukum. Dalam perjalannya, DII/TII berhenti ketika semua pimpinannya tertangkap atau terbunuh pada awal tahun 1960 -an. ${ }^{5}$

Fundamentalis-radikalis Islam muncul lagi pada awal tahun 1970-an dan 1980-an, misalnya melalui kelompok-kelompok seperti Komando Jihad. Kelompok ini menyatakan perang terhadap komunisme di Indonesia. Banyak dugaan bahwa kelompok ini dimanfaatkan intelejen pemerintah Indonesia saat itu untuk melawan komunisme. Disamping itu, gerakangerakan ini dijadikan legitimasi bagi pemerintah untuk melarang dan menindak tegas gerakan Islam garis keras di Indonesia, untuk memotong kaitan gerakan tersebut dengan partai politik yang menggunakan isu agama 
dalam kampanye. Usaha tersebut tampaknya berhasil, dan gerakan fundamentalis-radikal menjadi stigma jelek untuk beberapa waktu. ${ }^{6}$

Dalam tradisi pemikiran teologi keagamaan, fundamentalisme merupakan gerakan untuk mengembalikan seluruh perilaku dalam tatanan kehidupan umat Islam kepada Al-Qur'an dan hadis. ${ }^{7}$ Sebutan fundamentalisme juga bisa dimaknai sebagai istilah yang bermaksud untuk menunjuk kelompok pengembali (revivalis) Islam. Sementara, yang dimaksud radikalisme merujuk pada gerakan yang berpandangan kolot dan sering menggunakan kekerasan dalam mengajarkan keyakinan mereka. ${ }^{8}$

Sejauh ini memang belum ada kesepakatan diantara pakar terkait istilah yang tepat untuk menggambarkan gerakan radikalisme Islam. Fazlur Rahman, intelektual muslim asal Pakistan menyebutnya dengan neorevivalisme atau neofundamentalisme, yakni sebuah gerakan yang bersemangatkan anti Barat. ${ }^{9}$ Kendati demikian, ada ciri-ciri yang tampaknya menjadi kesepakatan bersama sebagai benang merahnya, yakni absolutis, skripturalis, opositionalis, puritan dan radikal. ${ }^{10}$ Ciri-ciri lain bisa dipahami dari tindak-tanduk gerakan Islam fundamentalis-radikal sebagai bentuk konkrit atau manifestasinya dilapangan, seperti: kelompok fundamentalisradikal tidak jarang ditemui kerap melakukan berbagai kekerasan sosial yang destruktif dan anarkhis atas nama Islam. Sebagai misal adalah sweeping terhadap warga negara asing (terutama AS, Inggris, Australia), merazia media massa cetak berbau pornografi, melakukan pengrusakan kafe dan club-club malam dan sebagainya. ${ }^{11}$

Mudah terbaca oleh kita bagaimana geliat kelompok-kelompok fundamentalis-radikal hadir mewarnai dinamika kehidupan Indonesia. Selain gencar menyuarakan penerapan syariat Islam secara terang-terangan dan melakukan kekerasan fisik, kelompok fundamentalis-radikal juga tidak jarang melakukan kekerasan non-fisik. Yakni, kekerasan non-fisik yang terekspresi melalui kecenderungan yang dengan mudah mengeluarkan fatwa murtad, kafir, syirik dan semacamnya, bahkan kepada sesama muslim. Tidak adanya rule of the game yang jelas dimasa transisi membuat kelompok Islam fundamentalisme-radikal ikut berupaya merebut momentum untuk mempengaruhi opini publik tentang kebenaran sikap mereka. ${ }^{12}$

Seperti telah disebut diatas, kelompok fundamentalis-radikal terobsesi dengan cita-cita penerapan syariat Islam. Bahkan -seperti akan terlihat didepan-, Hizbut Tahrir Indonesia (HTI) dan Majelis Mujahidin Indonesia (MMI) menginginkan lebih jauh lagi; yakni pembentukan negara Islam dalam bentuk kekhalifanan Islam. Isu yang selalu diusung oleh kelompok semisal dengan HTI dan MMI adalah pemberlakuan kembali Piagam 
Jakarta. Piagam "kontroversi" ini merupakan bagian penting dari tuntutan formalisasi syariat Islam yang memberi pijakan pada konstitusi. Kendati dalam perjalanannya proses ini gagal, kelompok Islam fundamentalisradikal tidak lantas mundur. Dibeberapa-daerah, mereka membentuk komite penegakan syariat Islam; Aceh, Sulawesi Selatan, Sumatera Barat, Jawa Barat, Bangkalan Madura dan lain-lain. Pemberantasan maksiat juga menjadi agenda utama yang tidak dilepaskan dari gerakan fundamentalisradikal. $^{13}$

Untuk menyebut beberapa saja, gerakan-gerakan atau organisasi sosial-masyarakat yang termasuk kategori fundamentalisme-radikal adalah Laskar Jihad (LJ), Front Pembela Islam (FPI), Majelis Mujahidin Indonesia (MMI), ${ }^{14}$ Jamaah Ikhwan al-Muslimin Indonesia (JAMI), dan lain-lain. Pemimpin utama LJ adalah Ja'far Umar Thalib, FPI adalah Habib Rizieq Shihab, MMI adalah Abu Bakar Ba'asyir, JAMI adalah Al-Habshi. ${ }^{15}$ Selain yang telah disebut diatas, ada Hizbut Tahrir Indonesia (HTI), ${ }^{16}$ Forum Umat Islam Indonesia (FUI), Laskar Mujahidin (LM), Gerakan Pemuda Islam, FKASWJ, ${ }^{17}$ Forum Betawi Rembug (FBR) dan masih banyak lagi lainnya. Terkait kelompok-kelompok fundamentalisme-radikal yang ada di daerahdaerah misalnya Forum Pemuda Islam Surakarta, Komite Persiapan Penegakan Syari'at Islam di Banten, Gerakan Penegak Syari'at Islam di Yogyakarta, Lembaga Pengkajian Penerapan Syariat Islam di Pamekasan, Lembaga Pengembangan dan Pengkajian Syariat Islam di Sukabumi, Front Thoriqatul Jihad di Kebumen dan lain-lain. ${ }^{18}$

Meminjam konsepsi yang digunakan Azumardi Azra, kelompokkelompok atau organisasi-organisasi demikian disebut dengan "salafiradikal" yang dengan gigih mengusung Islam murni atau Islam otentik. Kelompok-kelompok ini dapat dikategorikan sebagai kelompok "salafi radikal", yang berorientasi kepada penegakan dan pengamalan "Islam yang murni", "Islam autentik" yang dipraktekkan nabi Muhammad dan para sahabatnya. Mereka disebut sebagai "salafi radikal" karena mereka cenderung menempuh pendekatan dan cara-cara keras untuk mencapai tujuan, daripada dengan pendekatan dan cara-cara damai dan persuasif. ${ }^{19}$

Hampir senada dengan Azumardi Azra, menurut Ketua Umum PB NU, Said Aqil Sirajd, kelompok-kelompok fundamentalisme-radikal berjuang untuk menegakkan cita-cita yang mencakup persoalan hidup secara umum, seperti keluarga atau institusi sosial lain, berjuang dengan kerangka nilai atau identitas tertentu yang diambil dari warisan masa lalu maupun konstruksi baru. Selain itu, kelompok ini juga berjuang melawan musuh-musuh tertentu yang muncul dalam bentuk komunitas atau tata sosial 
keagamaan yang dipandang menyimpang. Mereka yakin bahwa perjuangan mereka diridai Tuhan. Pengaruh keagamaan dan politik dari Timur Tengah ke Indonesia bisa menjadi pemicu. Sejak Islam masuk ke nusantara, hubungan masyarakat Indonesia dengan Timur Tengah sangat kental. Transmisi itu dimungkinkan karena posisi Timur Tengah sebagai sentrum yang selalu menjadi rujukan umat Islam, baik untuk berhaji, ziarah, maupun belajar. Dari aktivitas tersebut, lalu muncul berbagai bentuk jaringan, baik jaringan keulamaan, jaringan gerakan dakwah, maupun jaringan gerakan politik. ${ }^{20}$

Pemahaman agama kelompok fundamentalis-radikal sangat literal $^{21}$ terhadap ajaran Islam, keyakinan yang sangat kuat bahwa Islam adalah satusatunya solusi untuk menyelesaikan berbagai krisis di negeri ini, perjuangan yang tak kenal lelah menegakkan syariat Islam, resistensi terhadap kelompok yang berbeda pemahaman dan keyakinan, serta penolakan dan kebencian yang nyaris tanpa cadangan terhadap segala sesuatu yang berbau Barat. ${ }^{22}$

Dalam praktik keagamaan, kelompok ini menekankan ketaatan yang penuh kepada apa yang dipraktikkan nabi dan generasi sahabat. Mereka berupaya keras untuk meniru cara hidup nabi, hingga hal-hal yang sekecilkecilnya. Anjuran untuk meningaktkan keimanan dan ketakwaan kepada Allah dan nabi berbanding lurus dengan anjuran untuk meninggalkan apa yang mereka sebut dengan bid'ah, khurofat dan takhayul. Purifikasi menjadi sangat penting dalam dakwah. Sementara dalam kehidupan bermasyarakat, kelompok ini menawarkan warna berbeda. Menampilkan ciri tersendiri antara lain dalam menampilkan fisik dan cara berpakaian; memelihara jenggot, memakai gamis dan celana panjang diatas mata kaki, serta mengenakan ikat kepala khas Arab, menjadi ciri kaum laki-laki. Adapun kaum perempuan mengenakan pakaian yang menutupi tubuh hingga tersisa wajah dan telapak tangan, bahkan ada yang memakai cadar. Dan masih banyak lagi praktik dan pengalaman dalam kehidupan sehari-hari. ${ }^{23}$

Di Indonesia, khususnya era pasca orde baru, beberapa penelitian bisa dirujuk disini. Setara Institute pernah merilis penelitiannya tentang fundamentalis-radikal agama yang menyebutkan ada 3 (tiga) gelombang untuk memahami lebih jauh tindak-tanduk fundamentalis-radikal, yakni konflik antar agama di Maluku dan Poso, proyek positivisasi syariat Islam di sejumlah daerah (Perda berlandaskan agama dan moralitas) dan penyerangan terhadap aliran sesat, anti kristenisasi, dan anti maksiat. Pada gelombang pertama, yakni konflik antar agama di Maluku dan Poso, konflik itu telah mengubah cara pandang keagamaan dan ketegangan masyarakat di 
seluruh Indonesia. Bahkan di beberapa daerah muncul sentimen terhadap agama lain karena melihat tayangan televisi, internet, dan media cetak dalam menggambarkan konflik di Maluku dan Poso. Laskar-laskar pun dikirim ke lokasi konflik sebagai wujud dari membela diri dan membantu umat Islam yang sedang diserang. ${ }^{24}$

Gelombang kedua adalah positivisasi syariat Islam di sejumlah daerah dalam bentuk Perda berlandaskan agama dan moralitas. Reformasi telah memunculkan perdebatan paling sengit tentang politik Islam tatkala proses amandemen UUD 1945 berjalan. Piagam Jakarta menjadi perdebatan publik, baik oleh kelompok yang mendukung maupun yang menolak. Piagam Jakarta yang dikenal dengan 7 kata yang telah dihilangkan, "dengan kewajiban menjalankan syariat bagi pemeluk-pemeluknya", telah menjadi pemicu dibukanya ruang Islamisasi. Bukan hal yang tabu membicarakan Islam di ruang publik. Tidak ada lagi yang takut menyuarakan Islam. Kata mereka, "ini adalah zaman demokrasi, zaman kebebasan berekspresi. Setiap warga negara berhak menyuarakan aspirasinya". Islamisasi di ruang publik betul-betul terasa. Menguatnya politik Islam membawa perubahan politik dan kultural Indonesia yang sejak rezim orde lama hingga orde baru selalu meminggirkan aspirasi Islam. Aspirasi Islam, seperti asas Islam, penegakan syariat Islam, dan tata kehidupan Islami mengisi ruang-ruang yang dulu dilarang oleh orde baru. Dari persoalan mode hingga politik, warna keislamannya begitu kentara. ${ }^{25}$

Gelombang baru dari gerakan Islam fundamentalis-radikal, yaitu penyerangan terhadap aliran sesat, anti kristenisasi, dan anti maksiat. Sasaran utama yang dituju adalah Jemaat Ahmadiyah dan aliran sesat lainnya (Lia Eden, Mushaddiq), tempat-tempat ibadah umat Kristen, dan tempat-tempat serta praktik yang dianggap maksiat. Penyerangan kelompok Islam radikal terhadap Jemaah Ahmadiyah di Parung merupakan aksi induk yang pada gilirannya menjalar ke daerah-daerah lainnya. Seakan menjadi magnet, penyerangan terhadap Ahmadiyah di Parung menjadi tren di berbagai daerah. Lombok, Kuningan, Majalengka dan daerah-daerah lain ikut menyerang Jemaat Ahmadiyah. Seperti sudah didesain secara nasional, terjadi gelombang penyerangan terhadap Ahmadiyah. Korban pun jatuh tak terhindarkan, terutama aset-aset organisasi, seperti gedung, masjid, dan bahkan rumah-rumah warga Ahmadiyah. ${ }^{26}$

Kecenderungan tindak-tanduk dengan cara kekerasan yang dilakukan oleh kelompok fundamentalis-radikal juga diakui Azumardi Azra, cendekiawan asal UIN Syarif Hidayatullah Jakarta. Sebagaimana namanya, gerakan Islam yang muncul pasca orde baru ini semakin meningkatkan 
kecenderungan "garis keras". Peningkatan garis keras ini sering disebut sebagai bangkitnya radikalisme. Indikator yang paling utama adalah kemunculan kelompok-kelompok atau organisasi-organisasi yang kelihatan lebih keras dan tegas (firm) - cenderung tanpa kompromi - untuk mencapai agenda-agenda tertentu yang berkaitan dengan kelompok muslim tertentu, atau dan bahkan dengan pandangan dunia (world view) Islam tertentu sebagai sebuah agama. Kesan garis keras itu agaknya pertama kali bisa terlihat dari nama dan terminologi yang mereka gunakan. Terdapat kelompok-kelompok yang menggunakan nama seperti Jundullah (tentara Allah), Laskar Jihad, dan Hizbullah (partai Allah) atau organisasi yang kelihatan lebih besar, seperti Front Pembela Islam (FPI). ${ }^{27}$

\section{MEMBUMIKAN ISLAM RAHMAH: ORMAS ISLAM MODERAT DAN TANTANGAN FUNDAMENTALIS- RADIKAL ISLAM DI INDONESIA}

Karakter, model atau corak keberagaman di Indonesia masih dominan berwajah moderat. Banyak kalangan mengakui, NU dan Muhammadiyah misalnya, merupakan representasi wajah moderasi Islam di Indonesia. ${ }^{28}$ Sejak lama NU dan Muhammadiyah, dua ormas terbesar yang dipunyai bangsa ini secara eksplisit sangat mengedepankan moralitas dan etika sosial (al-mashlahah al'ammah), menjungjung tinggi perdamaian dan keadaban serta menolak kekerasan. NU memiliki doktrin moderatisme (tawassuth) dan toleransi (tasamuh), sedangkan Muhammadiyah mempunya doktrin tauhid sosial dan amar makruf. Secara doktrinal dan teologis, kedua ormas ini telah mengukuhkan diri sebagai gerakan keagamaan yang mengutamakan inklusivisme, bukan eksklusivisme; pluralisme, bukan ekstrimisme. ${ }^{29}$

Dalam setiap kepemimpinan ormas agama NU maupun Muhammadiyah, watak Islam moderat terus mantap. NU di era kepemimpinan Hazim Muzadi misalnya. Sejak 1999-2004 Hazim Muzadi telah melakukan beberapa hal penting yang menunjukkan semakin terangkatnya karakter dasar sebagai penyeru Islam moderat. Sebagi contoh adalah saat geger formalisasi syariat Islam dan upaya pengembalian piagam Jakarta dalam UUD 1945. NU bersama Muhammadiyah dengan tegas menolaknya. Begitu pun dengan fenomena "kebangkitan" arus Islam fundamentalis-radikal yang tampaknya kian menunjukkan dominasi ditengah percaturan Indonesia. NU mampu menjadi penyeimbang untuk menunjukkan bahwa karakter Islam Indonesia bukanlah fundamentalisradikal, tapi moderat. Dalam percaturan Internasional, NU juga menjadi 
pertimbangan dan diperhitungkan banyak kalangan. ${ }^{30}$ Oleh karena itu, menghadirkan kembali pemikiran-pemikiran moderat yang telah ditoreh oleh Kiai Hasyim merupakan sebuah keniscayaan. Bagi NU dan kalangan muslim moderat pada umumnya, tak terkecuali Muhammadiyah, hal tersebut akan memberikan pencerahan dalam hal mengenali dan mengkaji kembali khazanah keislaman Indonesia, yang telah meletakkan dasar-dasar pemikiran keagamaan moderat dan gerakan keagamaan yang moderat. ${ }^{31}$

Sosok tokoh penting lain dari kultur NU yang turut menanamkan benih Islam moderat di Indonesia adalah KH. Hasyim Asy'ari. Ia dimata banyak kalangan telah menyelamatkan bangsa ini dari ancaman puritanisme, yang cenderung menginsitusionalisasi kekalahan dan kegagalan tersebut dalam paham keagamaan yang bersifat ekstrim. Pilihan untuk mengembangkan paham Ahlussunnah wal jamaah yang sangat identik dengan pergulatan intelektualisme dan penghargaan terhadap kemajemukan pemikiran yang sudah berkembang sejak dahulu kala. ${ }^{32}$

Menurut Khaled Abou el-Fadl sebagaimana dikutip oleh Zuhairi Misrawi, Islam moderat adalah paham yang mengambil jalan tengah, yaitu paham yang tidak ekstrim kanan dan tidak pula ekstrim kiri. Paham ini dikenal dalam al-Qur'an sebagai karakter dari ummatan wasathonm yaitu umat moderat, yang mengambil jalan tengah. Allah SWT berfirman dalam Al-Qur'an; "Dan kami telah jadikan kalian sebagai umat yang moderat" (Al-Qur'an surat Al-baqarah [2]: 143). ${ }^{33}$ Nabi Muhammad adalah seorang nabi yang senantiasa memilih jalan tengah bila dihadapkan pada pilihan dua kutub ekstrem. Dalam sebuah hadis nabi bersabda, "paling baiknya pekerjaan adalah yang paling moderat". Sebab itu, menurut Khaled, istilah moderat mempunyai akar yang kuat dalam khazanah Islam, yang merupakan karakter normatif dari mayoritas muslim di seantero dunia. Kalangan muslim Indonesia diantaranya merupakan salah satu bagian dari kelompok yang mengusung moderatisme. ${ }^{34}$

Islam moderat mengkampanyekan dimensi kelenturan, kesantunan, dan keadaban Islam. Islam sebagai penebar kasih, cinta dan sayang (rahmatan lil 'alamin) harus menjadi paradigma yang mengakar di tengah masyarakat. Hal ini menjad penting guna meminimalisir pandangan keagamaan yang selalu berwajah sangar dan keras yang digunakan secara sistematis oleh beberapa kalangan atau kelompok muslim.

Sebagian dari muslim ada yang ingin menampilkan bagaimana anggunnya nilai-nilai Islam dalam hamamayu hayunung bawono, sehingga Islam adalah kasih Allah yang diberikan kepada umat manusia. Muslim dengan wajah ini jauh dari sikap garang kepada siapapun, baik sesama 
muslim maupun non-muslim. Lebih dari itu kasih yang ada bukan hanya kepada sesama manusia tetapi juga alam seluruhnya. Kelompok Islam ini biasanya cenderung tidak ideologis apalagi formalis. Mereka lebih konsentrasi pada pelayanan umat yang akan menunjukan bagaimana Islam mampu memberi manfaat kepada umat manusia secara universal ketimbang mempersoalkan dasar negara syari'ah apalagi "nggebugi" orang-orang yang sedang di tempat hiburan atas nama amar ma'ruf nahi munkar. ${ }^{36}$

Corak Islam ini lebih menekankan bagaimana terjadi suasana hidup yang harmonis dengan keragaman hidup yang ada daripada menonjolkan benar-salahnya suatu agama. Kebenaran agama adalah kebenaran keyakinan bukan kebenaran empiris sehingga bisa buang-buang waktu dan energi jika hal ini yang dipersoalkan. Sementara persoalan kemanusiaan seperti kemiskinan, kesehatan dan kesejahteraan menjadi terabaikan. Dunia, dalam pandangan Islam rahmah adalah media untuk siapapun baik mukmin maupun kafir. Disinilah tempat perjuangan antara baik dan buruk untuk saling mempengaruhi tetapi tidak dapat dipaksakan termasuk agama sekalipun. Agama harus disampakan tetapi tidak untuk dipaksakan. Allah sendiri menyebut "iman kepada Allah dan Rasul-Nya" serta "jihad" sebaga tijarah, "dagangan" (al-Qur'an surat as\}-S\}aff: 10). Dagangan tentu tidak dapat dipaksakan kepada konsumen. Yang ada adalah bagaimana kita menjadi pedagang-pedagang yang baik dan ramah sehingga dagangan kita yakni "Islam" banyak yang berminat. Bagaimana orang berminat untuk beli jika yang menawarkan saja sudah terlihat sangar. ${ }^{37}$

Gerakan muslim moderat merupakan salah satu pilihan terbaik untuk membumikan toleransi. Gerakan muslim moderat merupakan landasan yang kuat dari teks, tradisi dan realitas kekinian. Wataknya yang senantiasa menolak kekerasan, radikalisme dan terorisme, membuktikan bahwa pandangan kalangan muslim moderat merupakan pandangan yang paling dekat dengan al-Qur'an. Dalam kaitannya dengan toleransi, kalangan Islam ini senantiasa terbuka dengan perbedaan tafsir keagamaan. Menurut mereka, perbedaan pada ranah tafsir dan penalaran hukum merupakan salah satu khazanah pemikiran Islam yang harus dijadikan titik tolak dalam mengembangkan tradisi ijtihad di kalangan muslim. Perbedaan tafsir dalam sejarahnya tidak menyebabkan kemunduran bagi umat, tapi sebaliknya yang menjadikan umat terbelakang adalah pemasungan terhadap tafsir keagamaan. ${ }^{38}$

Berbeda dengan gaya muslim yang eksklusif, kelompok muslim eksklusif cenderung monolitik, tertutup, bersikap kurang ramah, bahkan terkesan "memusuhi" terhadap penganut agama lain. Karakter berislam demikian biasanya direpresentasikan oleh kelompok Islam garis keras atau 
fundamentalis-radikal. Sebaliknya dengan muslim moderat, muslim moderat lebih menonjollkan keterbukaan dan cenderung pluralistik serta mencitacitakan terciptanya bagimana pluralitas agama tidak dapat menjadi pemicu konflik sosial, misalnya, tetapi menjadi alat pemersatu bangsa dengan landasan saling menghormati satu sama lain dan berlomba-lomba dalam kebaikan. ${ }^{39}$

Dalam pengertian lainnya, Islam moderat dalam memahami teks-teks agama, Al-Qur'an dan sunah misalnya, dipahami secara kontekstual dan bukan tekstual. Teks-teks agama dipahami secara membumi dan sesuai dengan situasi dan kondisi zaman. Kalangan moderat menolak memhami secara rigid dan tekstual, melainkan sebuah pembacaan yang kontekstual dan membumi. Teks-teks agama direproduksi sesuai semangat zaman. Tidak salah bila kalangan moderat tidak pernah menyerukan suara-suara perjuangan penerapan syariat Islam, baik dari NU maupun Muhammadiyah. Sebab dalam pandangan Islam moderat, Pancasila dan UUD 1945 sudah merupakan ideologi yang final dan tidak perlu diotak-atik lagi. Posisi syariat Islam dalam pandangan muslim moderat hanyalah berfungsi sebagai roh atau semangat yang menjiwai kehidupan berbangsa dan bernegara, bukan berfungsi sebagai hukum dalam negara itu sendiri. ${ }^{40}$

Sebagaimana Muhammadiyah, NU telah menganggap Pancasila dan UUD 1945 sebagai konsesus nasional yang sudah final dalam kehidupan berbangsa dan bernegara. NU juga telah menganggap NKRI sebagai bentuk final bagi bentuk negara Indonesia. Sebagai romas Islam terbesar di dunia, NU merasa bertanggungjawab atas keutuhan dan keselamatan bangsa dan negara. Karena itu, sikap reaksi NU yang sangat tegas terhadap kelompokkelompok garis keras yang mengusung ideologi negara Islam bisa mengancam terhadap keutuhan bangsa dan negara Indonesia, dan sebaliknya. Menghadapi ancaman kelompok-kelompok garis keras yang banyak bermunculan akhir-akhir ini, NU dan Muhammadiyah sebagai dua ormas terbesar di Indonesia sepakat untuk membendung gerakan mereka sekaligus menggalang kekuatan untuk terus mengkampanyekan Islam moderat. Kedua ormas ini mengabarkan kepada dunia bahwa kelompokkelompok garis keras sesungguhnya tidak merepresentasikan Islam. Mereka malah membajak Islam untuk kepentingan politik kelompok mereka sendiri. ${ }^{41}$

NU, sejak didirikan oleh Kiai Haji Hasyim Asya'ari dan beberapa Kiai karismatik di Surabaya pada tahun 1926, telah menjadi organisasi Islam terbesar di Indonesia. NU sejak awal selalu konsisten dengan sikapnya yang akomodatif sehingga di pandang sebagai pilar utama Islam moderat bersama 
Muhammadiyah. Baik NU maupun Muhammadiyah tidak menyetujui konsep negara Islam di Indonesia. Mereka tidak menyetujui formalisasi hukum syariat atau hukum Islam di Indonesia. Sebaliknya, mereka secara konsisten dan aktif mempromosikan ide-ide pluralisme dan dialog antaragama di Indonesia. ${ }^{42}$

Tokoh penting muslim moderat dari rahim NU juga bisa dilihat dari gaya pemikiran Abdur Rahman Wahid atau Gusdur. Gusdur selama hidupnya telah berupaya membuat anak bangsa dinegeri ini memahami bahwa Islam tidak menolak perubahan zaman. Islam juga tidak memperkenankan cara-cara kekerasan, radikalisme dan apalagi terorisme. Islam adalah agama perdamaian. Gusdur yang pada dasarnya lahir, besar dan berakar pada puritanisme, ternyata juga mengajarkan anak bangsa Indonesia untuk memahami dan menghargai perbedaan. Beliau menghargai seluruh ras, suku, budaya dan agama yang ada di Indonesia. Beliau mengajarkan bangsa Indonesia makna pluralisme dalam arti sesungguhnya. Gusdur dengan caranya sendiri berupaya menjalin komunikasi yang baik dengan berbagai tokoh lintas agama. Dengan semangatnya, beliau mengangkat kembali agama, kepercayaan dan kebudayaan komunitas minoritas Cina di Indonesia yang sebelumnya dipinggirkan, bahkan di hilangkan oleh rezim orde baru. Atas dasar rasa humanis yang luar biasa, beliau berupaya menggugah masyarakat Indonesia unyuk tidak menyakiti, melukai dan menghakimi orang-orang yang terkait Ahmadiyah. ${ }^{43}$

Lagi, meminjam Khaled Abou el-Fadl, ia menyebutnya dengan Islam puritan VS Islam moderat, kelompok puritan cenderung melihat setiap persoalan dengan menggunakan palu bid'ah, sesat dan menyimpang. Sedangkan kalangan moderat cenderung toleran dan adil dalam melihat setiap persoalan dari berbagai aspek. Lalu, jika terdapat perbedaan, yang dikedepankan oleh kalangan muslim moderart adalah toleransi dalam konteks persaudaraan kemanusiaan. ${ }^{44}$

Di Indonesia, kalangan muslim moderat bisa dibilang mayoritas. Hanya saja, persoalannya kemudian adalah mereka kelompok mayoritas yang diam. Sedangkan kalangan puritan pada dasarnya adalah minoritas yang lantang. Maka yang terlihat kalangan puritan yang merupakan kelompok mayoritas yang dengan mudah membolak-balikkan keadaan. Apalagi mereka terkesan vokal dalam setiap peristiwa, yang dapat membentuk opini publik dan seakan-akan mereka satu-satunya representasi dari Islam. Oleh karena itu, kalangan Islam moderat musti membentangkan kembali khazanah moderasi Islam, kususnya dalam konteks keindonesiaan. Ditengah kuatnya arus transnasional gerakan keagamaan, kalangan moderat 
harus melakukan sesuatu dalam konteks membendung pengaruh mereka dalam ruang publik. ${ }^{45}$

Dalam konteks ini Alfan Alfian M, peneliti Katalis dan ACG Consulting Group, Jakarta, mengatakan perlunya agenda nyata dari kalangan Islam moderat, tak sekadar bergelut di dataran wacana, tetapi juga aksi nyata di lapangan. Mereka lebih dulu harus merapatkan barisan, antara sesama elemen Islam moderat, mengingat tugas berat, meneguhkan peran positif Islam dalam merajut keharmonisan dalam konteks multikulturalisme Indonesia. Islam moderat bertugas mencairkan kebekuan dengan menampilkan Islam dalam tema perdamaian, dialogis dan toleransi. Islam moderat, bila ditinjau dari pilihan atas doktrin amar makruf nahi munkar, pilihannya lebih terletak pada amar ma'ruf (menyeru kepada kebaikan). Maka, pendekatannya lebih dialogis dan persuasif. Kelompok Islam moderat juga bertugas mengerem tindakan fatal kelompok fundamentalisradikal. Hanya saja, belakangan ini Islam moderat menurut gregetnya, kurang memiliki daya greget, dan seolah kurang mampu menjawab banyak pertanyaan seputar realitas dinamika keislaman dan keindonesiaan belakangan, kecuali lewat wacana-wacana semata. Harus diakui, inilah yang membuat kelompok fundamentalis-radikal mengerucut, seolah mengambilalih hal-hal yang di lapangan tidak dilakukan kalangan moderat. ${ }^{46}$

Sekretaris PP Muhammadiyah, DR Abdul Mu'thi pernah mengungkapkan, untuk menguatkan posisi kelompok Islam moderat perlu dilaksanakan dua langkah strategis. Pertama, diperlukan konsolidasi internal ormas Islam moderat. Terutama penguatan ideologi organisasi. Ormas garis keras mudah menyusup karena kurangnya pembinaan dan lemahnya wawasan keislaman. Kedua, adanya penguatan politik dan hukum. Terutama kepada pemerintah dan aparat penegak hukum agar menindak pelaku tindak kekerasan. Pembiaran tindak kekerasan merupakan preseden buruk yang dapat memicu terjadinya tindak kekerasan serupa. ${ }^{47}$

Begitu pun dengan Haidar Nashir, menurutnya di tengah banyak kutub ekstrem gerakan Islam kontemporer, Muhammadiyah dituntut untuk hadir sebagai ideologi Islam alternatif, yang menawarkan pandangan Islam yang berkemajuan yang serba melintasi dan mengungguli. Muhammadiyah perlu koreksi diri, jangan sampai terjebak pada kecenderungan yang tidak positif, yakni kering dari pemikiran tidak sebagaimana kaum neomodernisme Islam, kalah dalam militansi dan keteguhan sikap sebagaimana gerakangerakan neorevivalisme Islam, sedangkan dalam model-model praksis amaliah pun mulai ketinggalan baik dari gerakan-gerakan Islam baru maupun dari gerakan Islam tradisional yang dulu dikritiknya secara tajam. ${ }^{48}$ 
Di sinilah pentingnya memahami dan melakukan aktualisasi kembali terhadap gagasan-gagasan dasar dan pandangan Islam yang selama ini dianutnya, yang secara substantif bermuara pada Islam yang berkemajuan. Bagaimanapun ideologi reformis-modernis Muhammadiyah yang berbasis pada Islam yang berkemajuan, meniscayakan kekayaan konsep, perspektif, dan model-model gerakan yang harus lebih unggul ketimbang yang lain manakala ingin meneruskan gerakan dakwah dan tajdidnya yang selama satu abad telah mengukir kisah sukses. ${ }^{49}[]$

\section{Catatan Akhir:}

${ }^{1}$ Imdadun Rahmat, Arus Baru Radikal Islam (Rev), (Surabaya: Penerbit Erlangga), h. 134 .

${ }^{2}$ Kajian tentang dinamika Islam berhaluan fundamentalisme-radikal di Indonesia telah banyak disorot oleh para pakar baik aktivis maupun akademisi dalam konteks keilmuan. Sebenarny, dalam membincangkan kelompok-kelompok Islam fundamentalisme-radikal bsia dibilang kompleks dan perlu pendalaman kajian agar menemukan secara utuh gambaran tetangnya; akar, genealogi, ideologi, sejarah, factorfaktor yang melatari dan sebagainya. Akan lebih komprehensif lagi bila diketengahkan diskusi historis baik dalamkonteks sejarah Indonesia maupun korelasinay dengan gerakan-gerakan Islam transnasional. Dalam kajian ini penulis akan banyak menyoroti dinamika gerakan Islam fundamentalisme-radikal yang muncul pasca orde baru dimana era inilah yang boleh disebut dengan kebangkitan fundamentalise-radikal.

3 Budhy Munawar-Rachman, Moh Shofan, Argumen Islam untuk sekularisme Islam progresif dan perkembangan diskursusnya, (Jakarta: PenerbitGrasindo, 2010), h. 116.

${ }^{4}$ Jajang Jahroni, Gerakan Salafi radikal di Indonesia (Jakarta: Rajawali Pers, 2004), h. 16.

${ }^{5}$ Budhy Munawar-Rachman, Moh Shofan, Argumen Islam untuk sekularisme Islam progresif dan perkembangan diskursusnya, h. 118.

${ }^{6}$ Jajang Jahroni, Gerakan Salafi, h. 18.

${ }^{7}$ Lihat misalnya dalam bukunya Kuntowijoyo, Identitas Politik Umat Islam, (Bandung: Mizan, 1997), h.49

${ }^{8}$ Nasution, Islam Rasional, (Bandung: Mizan, 1995), h.124.

9 Fazlu Rahman, Islam dan Modernitas: Tentang Transformasi Intelektual, (Bandung: Pustaka, 1995), h. 162.

10 Akhmad Elang Muttaqin, "Mengakhiri Radikalisme Islam" dalam Erlangga Husada, dkk., Kajian Islam Kontemporer, (Jakarta: Lembaga Penelitian UIN Syarif Hidayatullah Jakarta, 2007), h. 5.

${ }^{11}$ Lih. Khamami Zada, Islam Radikal: Pergolakan Ormas-ormas Islam Garis Keras di Indonesia, (Jakarta: Teraju, 2002). 
${ }^{12}$ Komarudin Hidayat dan Ahmad Gaus. (ed.), Islam, Ngera dan Civil Society: Gerakan dan Pemikiran Islam Kontemporer, (Jakarta: Paramadina, 2005), h. 493.

${ }^{13}$ Imdadun Rahmat, Arus Baru, h. 135.

14 Majelis Mujahidin Indonesia adalah organisasi yang bsia dikategorikan fundamentalisme-radikal. Kehadirannay sangat penting dalam memperkuat fundamentalisme-radikal di Indonesia. MMI merekrut anggotanya dari ebrbagai wilayah Indonesia dan ebrusaha mendekati organsiasi Islam yang sudah ada seperti Muhammadiyah dan NU, agar mau menjadi pendukung MMI. Hampir sama dengan FKASWJ, MMI jug amemiliki milisi dengan nam aJundullah yang berarti tentara Allah. Lihat Afadhal (ed.), Islam dan radikalisme di Indonesia, (Jakarta: Yayasan Obor Indonesia, 2005), h. 122.

${ }^{15}$ Khamami Zada, Islam Radikal, h. 6-7.

${ }^{16}$ HTI terinspirasi oleh gerakan Internasional dengan nama serupa. Kelompok in ibis adibilang belum memiliki pengikut yang banyak disbanding FKASWJ maupun MMI. Kendati demikian, kehadirannay sangat penting akrena merupakan kelompok fundamentalisme-radikal yang mempunyai konseplumayan jelas. HTI menggunakan pendidikan dalam arti longgar sebagai media, seperti internet atau publikasi lainnya. Selain itu, HTI jug akerap melakukan demonstrasi, fundamentalisme-radikal yang vocal. Cara-cara demikianlah yang menarik perhatian public terkait cita-citanta dalam menerapkan syariat islam dan mendirikan khilafah Islam. Lihat Afadhal (ed.), Islam dan radikalisme), h. 124.

${ }^{17}$ FKASWJ adalah Forum Komunikasi Ahli Sunnah Wal-Jamaah yang didirikan oleh oleh Ja'far Umar Thalib, seorang vetran perang Afganistan. Kelompok ini memiliki sebuah milisi yang disebut Lasykar Jihad, yang telah eberhasil mengirimkan anggotanya untuk membela umat Islam yang berperang melawan Kristen di Ambon. Lihat Afadhal (ed.), Islam dan Radikalisme, h. 123.

${ }^{18}$ Sebagai catatan, menurut Haedar Nashir, orientasi dan aktulaisasinya memiliki perbedaan antar kelompok satu dan lainnya. Bila MMI orientasi dan tujuannya lebih menekankan pada tegaknya syariat Islam -biarpun tetap mendukung kekhalifahan Islam, HTI lebih kuat cita-cita nya dalam hal orientasi politik, yakni membentuk kekhilafahan Islam atau Negara khilafah. Lihat Haedar Nashir, Gerakan Islam Syari'at: Reproduksi Salafiyah Ideologis di Indonesia, (Jakarta: PSAP Muhammadiyah, 2007), h. xii.

${ }^{19}$ Azyumardi Azra, "Radikalisasi Salafi Radikal", Tempo, Desember, 2002.

${ }^{20}$ Said Aqil Siradj, “Akar Gerakan Islam Radikal”, Jawapos, 28 Juli 2009.

${ }^{21}$ Salah satu kecenderungan kaum radikalis adalah skripturalis atau literalis dalam menafsirkan teks-teks agama; meniolak studi kritis semisal hermeneutika, sebuah kajian yang berangkat dari tradisi filsafat bahasa yang mengasumsikan bahwa Al-Qur'an harus dipahami, ditafsirkan, diterjemahkan dan didialogkan dalam ranghka menfgasirkan realitas sosial. Lihat Komarudin Hidayat, Memahami Bahasa Agama: Sebuah Kajian Heremeneutik (Jakarta: Penerbit Paramadina, 1996), h.137,

${ }^{22}$ Said Aqil Siradj, “Akar Gerakan Islam Radikal”, Jawapos, 28 Juli 2009.

${ }^{23}$ Imdadun Rahmat, Arus Baru, h. 139. 
${ }^{24}$ Ismail Hasani (ed.), Radikalisme Agama di Jabodetabek \& Jawa Barat; Implikasinya terhadap Jaminan Kebebasan Beragamal Berkeyakinan, (Jakarta: Publikasi SETARA Institute, 2011), h. 31.

${ }^{25}$ Ibid, h. 32.

${ }^{26}$ Ibid, h. 37.

${ }^{27}$ Azyumardi Azra, "Muslim Indonesia: Viabilitas "Garis Keras" dalam Gatra, edisi khusus 2000, h. 44.

${ }^{28}$ Sikap moderasi Muhammadiyah sebenarnya sejak awal telah dibangun oleh pendiri organisasi ini, yaitu K.H. Ahmad Dahlan. Dikatakan, bahwa salah satu pelajaran yang paling penting dari kepemimpinan Ahmad Dahlan adalah komitmen kuatnya kepada sikap moderat dan toleransi beragama. Selama kepemimpinannya dapat terlihat adanya kerja sama kreatif dan harmonis dengan hampir semua kelompok masyarakat. Bahkan, dengan rekan Kristennya, beliau mampu mengilhami rasa hormat dan kekaguman. Contoh yang paling menarik dari kemampuan K.H. Ahmad Dahlan adalah mengikat persahabatan erat dengan banyak pemuka agama Kristen. Kenyataan, bahwa beliau dikenal sebagai orang yang toleran terhadap kaum misionaris Kristen, akan tetapi tidak berarti lantas beliau mengkompromikan prinsip-prinsipnya. Dia adalah seorang praktisi dialog antar-agama yang sejati, dalam pengertian dia mendengar apa yang dikatakan dan memperhatikan apa yang tersirat di balik kata yang diucapkan. Liha: Alwi Shihab, Islam Inklusif: Menuju Sikap Terbuka dalam Beragama, (Bandung: Mizan, 1997), h. 311-312.

${ }^{29}$ Zuhairi Misrawi, Pandangan Muslim Moderat: Toleransi, Terorisme, dan Oase Perdamaian, (Jakarta: Penerbit Buku Kompas, 2010), h. 173.

${ }^{30}$ Penerbit Buku Kompas, Nahdlatul Ulama: Dinamika Ideologi dan Politik Kenegaraan, (Jakarta: Penerbit Buku Kompas, 2010), h. 136.

${ }^{31}$ Zuhairi Misrawi, Hadratussyaikh Hasyim Asy'ari: Moderasi, keumatan, dan Kebangsaan, (Jakarta: Penerbit Buku Kompas, 2010), h. 16.

${ }^{32}$ Ibid. , h. 12.

${ }^{33}$ Ibid.

${ }^{34}$ Ibid., h. 14.

${ }^{35}$ Zuhairi Misrawi, Pandangan Muslim, h. 175.

${ }^{36}$ Tafsir, Jalan Lain Muhammadiyah, Menafsir Ulang Gerakan Dakwah Kultural Muhammadiyah Akar Rumput, (Jakarta: Al-Wasat Publishing House, 2010), h. 102.

${ }^{37}$ Ibid., h. 103.

${ }^{38}$ Zuhairi Misrawi, dkk., Al-Quran Kitab Toleransi, (Jakarta: Grasindo).

40 Ahmad Shidqi dan Gilang Desti Parahita, Tuhan di dunia gemerlapku, (Jogyakarta: Penerbit kanisius), h. 40.

${ }^{41}$ KH. Abdurahman Wahid (ed.), Ilusi Negara Islam, (Jakarta: Ma'arif Institute, 2009), h. 1998-1999.

42 Mohamad Sobary, NU dan keindonesiaan, (Jakarta: Mohamad Sobary PenerbitGramedia Pustaka Utama, 2010), h. 25. 
${ }^{43}$ Damien Dematra, Sejuta hati untuk Gus Dur: sebuah novel dan memorial, (Jakarta: PT Gramedia Pustaka Utama, 2010), h. 318.

${ }^{44}$ Zuhairi Misrawi, Hadratussyaikh Hasyim Asy'ari, h. 14.

${ }^{45}$ Ibid.

${ }^{46}$ Alfian M, "Momentum Kebangkitan Islam Moderat", KOMPAS, 1 Februari 2002.

${ }^{47}$ Suara Muhammadiyah, No.11/TH.KE-96 1-15 Juni 2011.

${ }^{48}$ Suara Muhammadiyah, No.17/TH.KE-96 1-15 September 2011.

${ }^{49}$ Suara Muhammadiyah, No.17/TH.KE-96 1-15 September 2011. 


\section{DAFTAR PUSTAKA}

Afadhal (ed.), Islam dan radikalisme di Indonesia, (Jakarta: Yayasan Obor Indonesia, 2005).

Alfian M, "Momentum Kebangkitan Islam Moderat", KOMPAS, 1 Februari 2002.

Azra, Azyumardi, "Radikalisasi Salafi Radikal", Tempo, Desember, 2002.

Azra, Azyumardi, "Muslim Indonesia: Viabilitas "Garis Keras" dalam Gatra, edisi khusus 2000.

Dematra, Damien, Sejuta hati untuk Gus Dur: sebuah novel dan memorial, (Jakarta: PT Gramedia Pustaka Utama, 2010).

Hasani, Ismail, (ed.), Radikalisme Agama di Jabodetabek \& Jawa Barat; Implikasinya terhadap Jaminan Kebebasan Beragamal Berkeyakinan, (Jakarta: Publikasi SETARA Institute, 2011).

Hidayat, Komaruddin, dan Ahmad Gaus. (ed.), Islam, Ngera dan Civil Society: Gerakan dan Pemikiran Islam Kontemporer, (Jakarta: Paramadina, 2005).

Hidayat, Komaruddin, Memahami Bahasa Agama: Sebuah Kajian Heremeneutik (Jakarta: Penerbit Paramadina, 1996).

Jahroni, Jajang, Gerakan Salafi radikal di Indonesia (Jakarta: Rajawali Pers, 2004).

Kuntowijoyo, Identitas Politik Umat Islam, (Bandung: Mizan, 1997)

Misrawi, Zuhairi, dkk., Al-Quran Kitab Toleransi, (Jakarta: Grasindo).

Misrawi, Zuhairi, Nahdlatul Ulama: Dinamika Ideologi dan Politik Kenegaraan, (Jakarta: Penerbit Buku Kompas, 2010).

Misrawi, Zuhairi, Pandangan Muslim Moderat: Toleransi, Terorisme, dan Oase Perdamaian, (Jakarta: Penerbit Buku Kompas, 2010).

Munawar-Rachman, Budhy dan Moh Shofan, Argumen Islam untuk sekularisme Islam progresif dan perkembangan diskursusnya, (Jakarta: Penerbit Grasindo, 2010).

Muttaqin, Akhmad Elang, "Mengakhiri Radikalisme Islam" dalam Erlangga Husada, dkk., Kajian Islam Kontemporer, (Jakarta: Lembaga Penelitian UIN Syarif Hidayatullah Jakarta, 2007).

Nashir, Haedar, Gerakan Islam Syari'at: Reproduksi Salafiyah Ideologis di Indonesia, (Jakarta: PSAP Muhammadiyah, 2007).

Nasution, Harun, Islam Rasional, (Bandung: Mizan, 1995). 
Rahman, Fazlur, Islam dan Modernitas: Tentang Transformasi Intelektual, (Bandung: Pustaka, 1995).

Rahmat, Imdadun ,Arus Baru Radikal Islam (Rev), (Surabaya: Penerbit Erlangga).

Shidqi, Ahmad, dan Gilang Desti Parahita, Tuhan di dunia gemerlapku, (Jogyakarta: Penerbit kanisius).

Shihab, Alwi, Islam Inklusif: Menuju Sikap Terbuka dalam Beragama, (Bandung: Mizan, 1997).

Siradj, Said Aqil “Akar Gerakan Islam Radikal”, Jawapos, 28 Juli 2009.

Sobary, Mohamad, NU dan keindonesiaan, (Jakarta: Mohamad Sobary PenerbitGramedia Pustaka Utama, 2010).

Suara Muhammadiyah, No.11/TH.KE-96 1-15 Juni 2011.

Suara Muhammadiyah, No.17/TH.KE-96 1-15 September 2011.

Suara Muhammadiyah, No.17/TH.KE-96 1-15 September 2011.

Tafsir, Jalan Lain Muhammadiyah, Menafsir Ulang Gerakan Dakwah Kultural Muhammadiyah Akar Rumput, (Jakarta: Al-Wasat Publishing House, 2010).

Wahid, KH. Abdurahman, (ed.), Ilusi Negara Islam, (Jakarta: Ma'arif Institute, 2009).

Zada, Khamami, Islam Radikal: Pergolakan Ormas-ormas Islam Garis Keras di Indonesia, (Jakarta: Teraju, 2002).

Zuhairi Misrawi, Hadratussyaikh Hasyim Asy'ari: Moderasi, keumatan, dan Kebangsaan, (Jakarta: Penerbit Buku Kompas, 2010). 